By JEROME K. WILCOX

\title{
A Documents Division in World War II
}

This is another in the series of wartime reports from the Berkeley campus of the University of California.

IN February 1944 the documents divi$\mathrm{I}_{\text {sion at }}$ the University of California Libráry was six years old. A brief review of its accomplishments during that period may be in order before any statements are made concerning its current use by government and war agencies. The primary object of the division, from its inception, has been to give personal assistance to faculty, students, and others in locating, using, and interpreting public documents. It is the only unit in the library where acquisition has been combined with service. Adequate service in the public document field can only be maintained so long as the personnel keeps up to the minute with government organization and new publications. The documents staff has therefore been responsible for acquisition and for keeping the collection up to date. There have been some handicaps-the chief one being lack of space, which is not unique in the library. Of late a second has been the inability because of war conditions to acquire sufficient student and clerical help, which unfortunately has placed upon the professional staff an undue amount of routine detail. In spite of this, however, the chief purpose of the division remains public service.

With the establishment of the division, all uncataloged and unbound federal, state, and foreign public documents were placed therein. The comparatively small amount of municipal material, principally from large cities, was thrown into the state group. ${ }^{1}$ To facilitate finding everything readily, the publications were arranged first in three large categories: federal, state, and foreign ; and second, in each of these groups, alphabetically by the inverted name of the issuing agency, e.g., Census Bureau rather than Bureau of the Census or Department of Commerce. Bureau of the Census.

The catalog in the division will ultimately be a union catalog. It will contain, first, an author or agency list of all of the public documents appearing in the general library's public catalog; second, the current record cards for all governmental periodicals and serial publications, as well as temporary cards for various separates before they are cataloged and classified; and third, a record of all of the public documents located in departmental or special libraries on the Berkeley campus. Of these three groups, the first and second are nearing completion. Progress is being made in recording the third, as the division now has records of the public documents contained in the libraries of the Bureau of Public Administration, forestry department, and Giannini Foundation. Quite a number of other departmental libraries also have public documents. The two largest

${ }^{1}$ Collecting California municipal and county documents is a function of the Bureau of Public Administration. 
units whose holdings are not yet incorporated in the catalog are the law library and the Bancroft Library.

The objects of throwing all of these data into one file are to give the reader a call number indicating general library stack location, to advise him what department has the document if it is not in the general library, or actually to direct him to the document in the uncataloged collection in the division.

The union catalog is maintained as an author or agency list with no subject entries. Subject approach is entirely through the very complete collection of guides, bibliographies, and reference tools to public documents and their use, located in the division. In addition, there is a complete collection of the blue books" or manuals of the forty-eight states, as well as the official or national yearbooks, blue books, statistical yearbooks, etc., for all foreign countries, including British and French colonies. The yearbooks and blue books have been brought together here because many times they furnish keys or clues to official information through footnotes, etc., by means of which the staff can give the patron fuller data from the more detailed reports.

The success of any documents division is contingent on an adequate professional personnel. Fortunately, at California the personnel has been excellent from the beginning. Its members are interested and enthusiastic and competent to find such material as is requested.

\section{Material on World War II}

The documents division has been attempting, ever since the beginning of the national defense program, to maintain a complete and comprehensive collection of all federal and state government publications pertaining to World War II. In the state field, the strongest collection is composed of the publications of the forty-eight state defense and war councils. In the federal field, emphasis has been placed on acquiring printed, processed, and pressrelease material from national and regional offices and local offices on the Pacific Coast, particularly those in California. The library is one of one hundred designated by the Overseas Branch of O.W.I. to receive after the war a set of its secret and restricted publications and to get immediately as published all nonsecret pamphlets and periodicals. The servicemen's papers of the Army, Navy, and Marine Corps are being acquired from the camps and military and naval stations within the area of the Ninth Service Command of the Army. In addition, attempts are being made to acquire the overseas papers of the Army and Navy units, such as Yank, Stars and Stripes, C.B.I. Round$U_{p}$, The Aleut ( $\mathrm{V}$-mail edition), etc. One of the strongest collections thus far is that concerning the Japanese evacuation and relocation programs, which includes all material of the War Relocation Authority, as well as papers and other publications from the evacuation and relocation centers.

\section{Foreign Publications}

In the foreign field, attempts are being made to acquire the official war publications insofar as possible. Since September 1939 the library has been a subscriber to the British Ministry of Information Press Release Service, whose items, with only two exceptions, have arrived regularly each month, thanks to the American and British navies. A very extensive collection has been built up of publications and periodicals of the European governments in exile and their national groups located in London, the United States, and elsewhere. About the time of America's entrance into the 
war, there was also acquired a set of the German military orders, rules, and regulations for occupied territories. Recently a two-year file of the Eritrean Gazette of the British Military Administration in Eritrea was added.

The World War II collection of public documents is kept together as a unit except for restricted and confidential pieces, which have been withdrawn and placed under lock and key for the duration. This method of handling has made all items readily available. Furthermore, federal, state, and Canadian publications are indexed in Official War Publications compiled by J. K. Wilcox (comprising seven volumes to date) which supplies a subject approach to this part of the collection.

The division has had continual use by representatives of war agencies, war industries, and individual organizations seeking information to aid them in their relation to governmental departments. The data sought by these groups usually require considerably more searching by the division's personnel than do the average questions submitted by students.

One of the most consistent governmental users is the Army Map Service of the Corps of Engineers which has regularly borrowed topographic and land survey reports, geological surveys, and statistical annuals of countries to which American troops are being sent. The Army Recruiting Service in San Francisco drew upon the files of Congressional Records and House and Senate hearings at the time of the organization of the WACs in order to keep in touch with the changing provisions of the measure establishing it.

\section{O.W.I. Overseas Branch}

From time to time the O.W.I. Overseas Branch has called for files of reports and for statistical and popular information about various Asiatic countries. It has also made use of the directories of official personnel of these governments.

The War Relocation Authority and the W.C.C.A. have made considerable use of early immigration figures and have also made close study of the Dies and LaFollette committees' hearings.

For the Twelfth Naval District the division has provided information on varied topics such as the cultivation of common crops in tropical countries and early naval regulations and early legislative action bearing upon naval procedure in the present war. The Legal Division of the Office of Naval Intelligence regularly checks the university's file of hearings, documents, and reports in order to keep up with current Washington legislative activity on matters which interest the Twelfth Naval District. Personnel connected with the Twelfth Naval District Intelligence Office have been studying material relative to the geology, topographical features, coastal terrain, highways, and agriculture of $\mathrm{Pa}$ cific areas under control of the Japanese.

Closing of the several libraries formerly maintained by the U. S. Department of Agriculture in the East Bay area has resulted in numerous inquiries from agencies formerly served by their own libraries. They include the California Forest and Range Experiment Station, which has been following federal action on guayule and foreign forest product production figures, as well as O.P.A. regulations affecting timber products.

The U. S. Bureau of Agricultural Economics has sought statistical information in connection with the Food for Freedom program, postwar planning, the Central Valley Project, etc.

Turning to the nongovernmental side, the tracing of War Production Board orders, O.P.A. regulations, and other gov- 
ernment orders and regulations is one of the commonest uses of the collection made by individual users. Among these users might be mentioned the radiation laboratory on the campus and the Pacific Gas and Electric Company. For the radiation laboratory, certain British government documents were traced and secured. The Pacific Gas and Electric Company also has made use of British and Canadian studies on overtime pay and wages in war plants.

Another group of documents-federal specifications upon which contract applications are based-have had considerable use. In one instance a steel pipe specification not available elsewhere was rushed to a war plant subcontractor in order that a priority application might meet a deadline.

The Selective Service System manual and its local board letters have been "best sellers" among individuals who have not found sufficient information available at draft board offices.

During the meat crisis the wholesale butchers of San Francisco drew upon the resources of information on the cutting, grading, and standardization of beef, lamb, and veal. Several representatives of con- sumer groups have studied the material on point rationing in England and Canada.

\section{War Labor Board}

The Tenth Regional War Labor Board has been interested in data concerning demobilization of industry and postwar industrial plans. At one time it made heavy use of certain hearings on manpower. Some of these hearings were borrowed and forwarded by air mail to Los Angeles for board meetings.

There has been a general increase in the use of early patent material, especially in chemistry and aircraft. One of the recent searches was the running down of all patents for devices on aircraft carriers.

All the demands for service enumerated above have been in addition to the regular use by faculty and students. In general, 75 per cent of the requests in the division are for federal publications, the remaining 25 for state and foreign publications.

It would appear that the documents division has performed, and is performing, a real service to faculty, students, and the community, and thus is making a useful contribution to the war effort.

ON THE BASIS of figures taken from the Unted States Office of Education College and University Library Statistics, 1939-40, Walter Crosby Eells has drafted certain criteria for the resources and service of junior college libraries. The undertaking is described in an article entitled "Junior College Library Criteria" in the Junior College Journal (15: 160-65, December 1944), and the extent to which private and public junior colleges respectively conform to the criteria is set forth in a chart which accompanies Dr. Eells's article and also has been published separately. 